\section{Artículo \\ Confinement narratives: TV advertising during the coronavirus outbreak in Spain ${ }^{1}$}

\author{
Jorge Grau-Rebollo² \\ 0000-0003-2709-8696
}

Universitat Autònoma de Barcelona, España

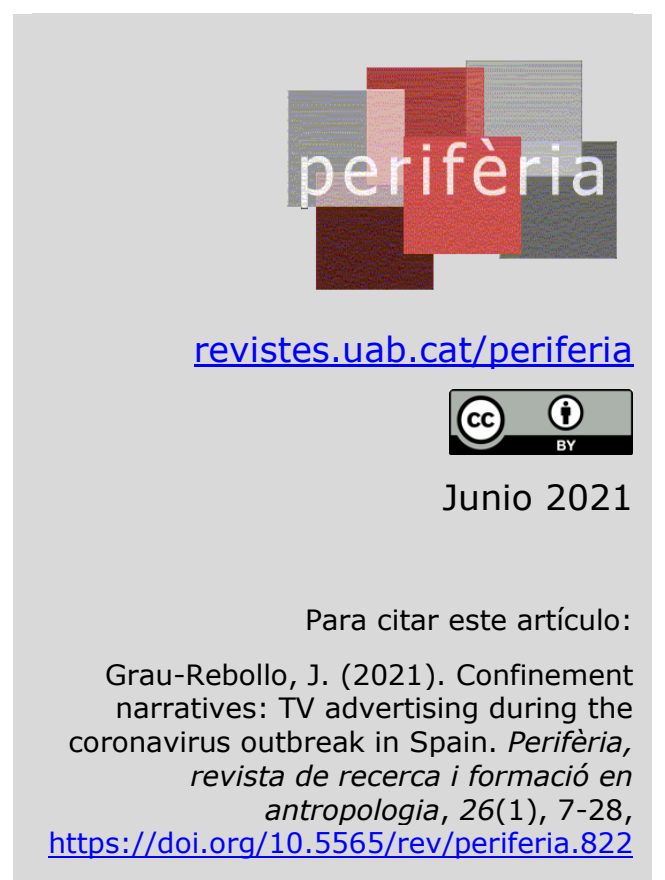

Abstract

Spain had been one of the worst affected countries during the first wave of the coronavirus pandemic, and by mid-March it had enforced one of the strictest lockdowns in Europe. As ethnographers, we have to deal with the unexpected (Canals, 2020) and cultural narratives embedded in widely broadcast audiovisual productions can be a key source for analysing social discourses and prevalent images during exceptional periods. Of these productions, TV advertising can be extremely valuable, with its intentional micro-stories of everyday life that condense selfcontained, meaningful audiovisual tales into less than 60 seconds.

I thematically examine here cultural narratives on the quarantine and subsequent de-escalation process in Spain by analysing a sample of 32 spots from 17 different brands and institutions in two different rounds of advertising. Among the recurrent tropes, a consistent storyline on a new sense of communitas is forged by emphasising resilience and continuity as cornerstones for a more robust concept of togetherness based on the idea of mutuality of sharing - drawing upon Sahlins' "mutuality of being" (2013).

Keywords: Advertising; Confinement; Coronavirus; Cultural narratives.

\footnotetext{
1 This work was supported by the Spanish Ministry of Science, Innovation and Universities under the Project Childrearing, Abandonment and Sociocultural Vulnerability: Situational Analysis and Proposals for Intervention (CSO2017-83101-C2-1-R).

${ }^{2}$ Contact: Jorge Grau Rebollo - jordi.grau@uab.cat
} 
Resumen: Narrativas de confinamiento: publicidad televisiva durante la epidemia de coronavirus en España.

España fue uno de los países más afectados durante la primera ola de la pandemia de coronavirus, y a mediados de marzo aplicó uno de los confinamientos más severos de Europa. Como etnógrafos, tenemos que hacer frente a lo inesperado (Canals, 2020) y las narraciones culturales que se insertan en producciones audiovisuales ampliamente difundidas pueden ser una fuente clave para analizar los discursos sociales y las imágenes predominantes durante períodos excepcionales. De estas producciones, la publicidad televisiva es extremadamente valiosa, al presentar microhistorias intencionales de la vida cotidiana, capaces de condensar relatos audiovisuales autónomos y significativos en menos de 60 segundos.

En este artículo analizo algunas narraciones culturales sobre el proceso de cuarentena y posterior desescalada en España mediante una muestra de 32 anuncios correspondientes a 17 marcas e instituciones diferentes, en dos rondas publicitarias distintas. Entre los resultados más evidentes, se evidencia la forja de un nuevo sentido de communitas al enfatizar la resistencia y la continuidad como piedras angulares para un concepto más cohesivo de unión basado en la idea de la mutualidad del compartir - basándose en la "mutualidad del ser" de Sahlins (2013)

Palabras clave: Publicidad; Confinamiento; Coronavirus; Narrativas culturales.

\section{Introduction}

Although pandemics seem to occur with a certain regularity (Potter, 2001), the reach of the COVID-19 outbreak has been unprecedented, mainly due to the global spread of new information technologies and mediated social interactions. Within such interconnection, audiovisual productions play a central role, not only in the form of movies, newsreels or documentaries, but also more ubiquitous media manifestations, such as TV advertising, which is inserted within nearly every TV format nowadays.

Politicians and scientists mostly agree on the unexpected nature of this pandemic, which caught all affected countries relatively unprepared. This unanticipated event has had a massive impact worldwide, yielding new perspectives on the "ethnographies of the unexpected" (Canals, 2020, p. 1), which may develop from 
different forms of cultural production, in different formats and through several channels.

Despite its novelty in scientific terms (the first warnings about SARS-CoV-2 were only made in December 2019), research studies on COVID-19 have grown exponentially since then. Academics from a wide range of disciplines have provided insights into the situation, but some fields of knowledge are still understudied. Advertising is one of the most relevant of these areas, given its ubiquity in the communications arena and the influence it exerts over the social fabric, not least through its configurations of cultural imagery and the use of stereotypes and other tropes in its mainstream audio-visual grammar (Browne, 1998; Farris, 2014).

Advertising has today become an influential social language (Caro Almela, 2007) that transforms representations of reality into cultural references, with direct consequences for how that same reality may be perceived and explained later on. This role as a cultural operator makes advertising a prime source for analysis of the unexpected, as it deliberately turns abstract notions into specific situations by precisely delineating features, contexts, dialogues and social interactions. This material substantiation is articulated in self-contained audiovisual stories of no more than a minute's length, making adverts micro-stories of everyday life. They are meticulously designed to portray and channel particular messages using specific visual, sound and textual methods and their meaning is meticulously agreed upon by the various agents involved in the development of the ad - from the customer/brand that funds it to the creative team that plans the campaign, including each link necessary to execute the idea.

In this article, I contribute to filling one major gap in research on cultural discourses and imagery during the COVID-19 outbreak. I propose to analyse major narratives during the coronavirus crisis in Spain by comparing audiovisual advertising campaigns that directly addressed that emergency, both at the beginning of the general lockdown in mid-March 2020 (the first round of advertising campaigns) and right after the beginning of the lockdown "de-escalation" process [desescalada] in early May (the second round). My main goal is to explore those ads explicitly tackling the social dimension of the pandemic in TV advertising in Spain: how are citizens portrayed under these circumstances? What major topics emerge within those narratives? Do they stress any specific social values? 
In order to answer these questions, the selected sample contains spots produced by the same funding companies and institutions during both rounds of advertising, so that similarities and differences between the same productive sources can be compared.

\section{Theoretical Framework}

Dealing with intentional narratives in audiovisual advertising during the pandemics may require several theoretical considerations altogether. For my purpose here, I consider two major issues: the first one deals with some of the pandemic crisis's significant economic effects, while the other points at the social relevance of advertising narrative content itself.

\section{On some social and economic consequences of the outbreak}

In a recent publication, Appadurai states that the social has been rediscovered by politics as: "[...] the concession by many states that they cannot face this crisis without the help of society at large, through practices of self-isolation, selfmonitoring, mutual caring and self-reporting" (2020, p. 1). Conversely, societies demand that politicians show effective political leadership (Hennekens et al, 2020), otherwise the legitimacy of these governments is promptly questioned and they are likely to suffer the consequences at the next polls (Biscop, 2020).

So far, Spain has been one of the countries that has been worst affected by the pandemic and, further, has undergone one of the strictest lockdowns in Europe, sparking public and academic debates about social and medical control, the necropolitics of triage (Anta, 2020), and other social concerns that could actually be extrapolated to wider cultural contexts (Žižek, 2020). Those debates have often been based on the opposition between political demands and public health services and have frequently been made from polarised positions, with recourse to powerful symbolic imagery, both conceptually and graphically. For instance, since the very beginning of the crisis, the Spanish media has referred time and again to healthcare personnel as "heroes", a qualification that has also been applied to other essential workers. In fact, this characterisation is by no means exclusive to the media (Sanfilippo et al, 2020), as distinguished academic journals have also honoured the "countless heroes of this pandemic", in the words of the Journal of the American 
Medical Association (Bauchner and Easley, 2020). Ironically, these "heroes" are facing working conditions marked by long-term precariousness and even find themselves on the frontier of new kinds of vulnerabilities:

Healthcare workers are destabilized, not just because they are exposed daily to the prospect of becoming unwell; they are exposed because the institutions that promised them security have failed to provide it [...] Crises, in other words, give rise to new kinds of vulnerabilities that take us by surprise, creating also new sensitivities, for better or worse, in the memories of those affected. (Napier 2020, p. 2).

Beyond the health crisis, the country also faces serious economic impacts in the short-term (He et al, 2020), which affect a large part of the productive sphere. In the midst of a tremendous breakdown that has reached nearly all social and economic sectors - and despite the great uncertainties that still surround the recession following the COVID peak - each business and commercial sector is trying to resituate itself, in order to ride out the storm and get through the crisis with the least possible damage:

The COVID-19 outbreak is likely to cause bankruptcy for many well-known brands in many industries as consumers stay at home and economies are shut down [...] While some businesses are struggling, some businesses are thriving. This is true for a number of Internet-based businesses, such as those related to online entertainment, food delivery, online shopping, online education, and solutions for remote work. (Donthu and Gustafsson, 2020, p. 285).

Advertising is by no means an exception. As Taylor points out: "While there are limits to what the industry itself can control, there is a clear need for advertisers and agencies to adapt to an environment that has dramatically [changed] almost overnight" (2020, p. 587). Such an abrupt conversion has run in parallel to a massive economic and social shift that ranges from the consolidation of certain purchasing patterns to the implementation of new communication routines. Thus, the online world has all of a sudden experienced unprecedented growth in many countries, at a time when online broadcasting had already reached an historical peak. Advertising business has followed the same path, with the share of commercial investment in the online sector in Spain exceeding funds poured into conventional communicative 
platforms, such as television, for the first time ever in 2019 (Kantar Media, 2020).

During that year, the advertising sector spent 13,145.6 million euros, which amounts to $1.06 \%$ of Spanish GDP (Sánchez ,2020). However, some initial sector forecasts estimate a downturn of $25.4 \%$ in overall investment and most advertisers ( $72 \%)$ have announced a budget reduction of between $10 \%$ and over 30\% (Scopen, 2020). The cutback in social advertising (i.e. that sponsored by public bodies, NPOs and NGOs) has been above average (26.3\%), ranking second after so-called "durable consumer goods" - appliances, industry, textiles and clothing, leisure time and computers - (a 30\% decrease), but well ahead of "mass consumer goods" - food and drink, beauty, cleaning, tobacco and pharmaceuticals - $(18.6 \%)$. Most of the commercials analysed fall within this last sector, as brands have used the coronavirus crisis as a strategic motif through which to reach their target audiences.

Globally, it is clear that the advertising industry ecosystem is having to cope with a serious recession (Vorhaus, 2020). According to the results of 152 interviews conducted in the United States with marketers and agencies at the beginning of April $2020,64 \%$ had held back a campaign for launch later in the year - which was 15 points higher than in mid-March $-44 \%$ had had to completely cancel a campaign before it was launched -10 points more $-50 \%$ had been forced to stop or pull a campaign in the middle of its run - 5 points higher - and only 24 percent had launched a new campaign that had not been previously scheduled (Advertiser Perceptions, 2020, p. 7). This last segment is the area I am interested in exploring here: campaigns launched due to unforeseen circumstances that forced creative teams to sharpen their wits to produce fast and effective commercials, which reinforced certain social values informed, in part, by the brand's marketing strategy.

Besides, some studies explore the appeal to corporate social responsibility (CSR) from the advertising industry during the COVID-19 crisis (Taylor, 2020; He and Harris, 2020), as consumers' trust in advertisers may become a crucial asset during breakdown selling times: "A firm's genuine and authentic CSR will build stronger rapport among its customers and the general public [...] The bond established between the brand and consumer during this crisis era can be more meaningful and lasting than during "peaceful" times" (He and Harris, 2020: 177). 


\section{On the social relevance of advertising narratives}

Although there have yet to be in-depth studies on the TV consumption of different audiences in different countries, some research has already noted that, in spite of digital media's importance as an information provider, the presence of television in the daily life of quarantined citizens during the COVID outbreak has increased (Casero-Ripollés, 2020). Nielsen Holdings, a global measurement and data analysis company on consumers and markets worldwide, has estimated that media consumption in the US has risen by up to $60 \%$ as a result of social distancing and outdoor restrictions (Nielsen, 2020a). In North Asian countries, where serious outbreaks occurred earlier, there has been similar growth: up to a $121 \%$ increase on the same period in the previous year in Taiwan and $43 \%$ in Hong Kong, with "TV viewing each day rising by 70 minutes to 7 hours and 40 minutes per day among current TV viewers' in mainland China" (Nielsen, 2020b). Within the European context, a study among young people showed an increase of $20 \%$ in the consumption of evening news on public television, this shift reaching $59.6 \%$ in Spain (CaseroRipollés, 2020, p. 5).

Beyond these figures, it is important to note that advertising companies use emotional strategies to better connect with their target audiences. In order to strength the emotional link between the prospective customer and the advertised item, creative teams employ production tactics that generally involve a process of identification - on the basis of factors such as ethnicity, age or gender (Torres and Briggs, 2007) - and empathetic connection with such audiences (Escalas and Stern, 2003). When advertising campaigns are funded by public institutions rather than private companies, these emotional appeals remain an essential communications tool, whether they are dealing with political issues (Brader, 2005) or humanitarian goals (Vestergaard, 2013).

Quite often, advertising narrative strategies intentionally bind specific social values to particular goods in order to create a more positive impact upon target audiences, although messages that are framed negatively sometimes seem to be more effective than those framed positively (Chang and Lee, 2009). In any case, previous research has also stressed the significance of highly emotive imagery, especially within the framework of natural or humanitarian disasters (Bennett and Daniel, 2002), as well as during financial crises (Lee, Chung, and Taylor, 2011). 
Whatever its strategic choices may be, advertising, as a form of social language (Caro Almela, 2007), gives us a unique opportunity to analyse audiovisual narratives that have been meticulously planned so as to embed a web of commercial purposes, social needs and contextual events into deliberate recreations of intended realities. Its recorded scenarios result from methodical planning of every single word, image, voice and post-production element, all of which come together to produce the optimal atmosphere by which to gain influence over audiences' intentions. Consequently, advertising has potential transformative power, as it ultimately seeks to actively intervene in collective attitudes and opinions, nudging them towards certain goods or ideas (Grau Rebollo, 2020).

\section{Methods}

\section{Sampling procedure}

In this article, I analyse cultural narratives embedded in audiovisual advertising during the coronavirus crisis in Spain, in the form of institutional advertising (sponsored by national or regional governments in Spain, or by public or private organisations, such as foundations or associations) and commercial spots: audiovisual units with a typical length of between 10 and 60 seconds that may use pre-recorded voiceovers (Martin, 2019). To do so, I applied these sampling criteria:

a) Spots must have been aired on TV and be currently available on the official institutional or corporate YouTube channel; other advertising formats aimed at specific digital media or based only on radio or the printed press were not included.

b) The units selected had to offer a communicative message regarding the social implications of the current crisis (self-promotional activities and purely informative instructions on how to behave or how to recognise COVID-19 symptoms were not included).

c) Privately funded brands had to belong to the "mass consumer goods" sector (Scopen, 2020).

d) Both institutional ads and commercials had to be aired either at the beginning of the general lockdown in Spain (mid-March 2020) or right after the beginning of

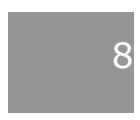


the de-escalation process (early May 2020).

e) Variants of the same spot of different lengths were not included.

f) Only companies and institutions with spots that formed part of both rounds of advertising campaigns were considered.

All the ads examined were aired on at least one major public TV station in Spain, regardless of how many times the same commercial may have been broadcast on other private or local TV channels. However, aside from TVE (Spain's national public broadcaster), only institutional ads from the Catalan government aired on Catalan public TV (TV3) could be sampled in this study, as no other public channels run by Spain's autonomous communities aired such adverts at the time of this research.

As the sampling process did not allow all possible units in the basic set to be included (Šerić and Ljubica 2018, p. 156), no randomisation procedure could be applied. Hence, I used an intentional sampling process, by retrieving the targeted selection from official channels on YouTube (a major open-access media repository for brands, official bodies and other institutions). Given the growing influence of the Internet in social life, the interest of organisations and brands in setting up corporate channels on major streaming and video-sharing platforms has increased over time, turning these into genuine video-catalogues of the brands' campaign repertoires.

\section{Sample characteristics and analysis procedure}

During the first weeks of lockdown, 23 different advertisements from 17 sponsors met the required criteria (the first round of advertising campaigns). By the beginning of the de-escalation period, the number of units that met the sampling criteria (and referred explicitly to the end of the full lockdown) dropped to 10 audiovisual advertisements from nine different sponsors (the second round of advertising campaigns). The list of private sponsors and commercials is as follows (table 1):

Table 1. Broadcasted advertisings (links retrieved from media corporate channels). 


\begin{tabular}{|c|c|c|c|}
\hline $\begin{array}{l}\text { SPOT/CAMPAI } \\
\text { GN }\end{array}$ & $\begin{array}{l}\text { BRAND / } \\
\text { INSTITUTI } \\
\text { ON }\end{array}$ & $\begin{array}{l}\text { LENGTH } \\
\text { (in } \\
\text { seconds) }\end{array}$ & URL \\
\hline \multicolumn{4}{|c|}{ First round of advertising campaigns } \\
\hline \#FrenarLaCurva & AUDI & $40^{\prime \prime}$ & https://youtu.be/dtTuvtg1DhM \\
\hline $\begin{array}{l}\text { Esto lo } \\
\text { superamos } \\
\text { juntos }\end{array}$ & $\begin{array}{c}\text { Bank of } \\
\text { Santander }\end{array}$ & $52^{\prime \prime}$ & https://youtu.be/93VNolalzPk \\
\hline $\begin{array}{l}\text { Queremos volver } \\
\text { a estar juntos }\end{array}$ & $\begin{array}{c}\text { Bank of } \\
\text { Santander }\end{array}$ & $30 "$ & https://youtu.be/sT_K2id_xhU \\
\hline $\begin{array}{l}\text { \#JuntosParaAyu } \\
\text { darte }\end{array}$ & Carrefour & $76^{\prime \prime}$ & https://youtu.be/nlC9e660KZs \\
\hline $\begin{array}{l}\text { \#YoMeQuedoENC } \\
\text { asa }\end{array}$ & Coca-Cola & $30 "$ & $\begin{array}{l}\text { https://www.facebook.com/coca } \\
\text { colauy/videos/154038629210156 } \\
(*)\end{array}$ \\
\hline $\begin{array}{l}\text { Porque estar } \\
\text { separados, jamás } \\
\text { nos había unido } \\
\text { tanto }\end{array}$ & $\begin{array}{l}\text { Regional } \\
\text { government } \\
\text { of Madrid }\end{array}$ & $58^{\prime \prime}$ & https://youtu.be/ee_QuFri_cM \\
\hline $\begin{array}{l}\text { La Primera } \\
\text { \#FUERZABAR }\end{array}$ & Cruzcampo & $60 "$ & https://youtu.be/AbxB3OkPMmE \\
\hline
\end{tabular}




\begin{tabular}{|c|c|c|c|}
\hline \#AguantaEnCasa & FIAB & $39^{\prime \prime}$ & https://youtu.be/T1PE8xbmMws \\
\hline $\begin{array}{ll}\text { Contenir } & \text { el } \\
\text { coronavirus } & \end{array}$ & $\begin{array}{c}\text { Catalan } \\
\text { government }\end{array}$ & $40^{\prime \prime}$ & https://youtu.be/wo2acOfQVIE \\
\hline Queda't a casa & $\begin{array}{c}\text { Catalan } \\
\text { government }\end{array}$ & $20^{\prime \prime}$ & https://youtu.be/NoUgfvC_Pus \\
\hline $\begin{array}{l}\text { Qui ens havia de } \\
\text { dir. }\end{array}$ & $\begin{array}{c}\text { Catalan } \\
\text { government }\end{array}$ & $60^{\prime \prime}$ & https://youtu.be/mzU2UjO47co \\
\hline $\begin{array}{l}\text { \#EsteVirusLoPar } \\
\text { amosUnidos }\end{array}$ & $\begin{array}{c}\text { Spanish } \\
\text { Government }\end{array}$ & $60 "$ & https://youtu.be/b6Fgddtx6aw \\
\hline $\begin{array}{l}\text { UN DÍA MÁS UN } \\
\text { DÍA MENOS. } \\
\text { \#EsteVirusLoPar } \\
\text { amosUnidos }\end{array}$ & $\begin{array}{c}\text { Spanish } \\
\text { Government }\end{array}$ & $58^{\prime \prime}$ & https://youtu.be/m76XbIITOHw \\
\hline $\begin{array}{l}\text { \#YoMeQuedoEnC } \\
\text { asa }\end{array}$ & IKEA & $30 "$ & https://youtu.be/7MWVGCfIZHA \\
\hline $\begin{array}{l}\text { Ahora más que } \\
\text { nunca, Juntos } \\
\text { para Siempre. }\end{array}$ & MAHOU & $88^{\prime \prime}$ & https://youtu.be/o3DjRI1fBYY \\
\hline $\begin{array}{l}\text { Quédate en casa, } \\
\text { juntos llegamos } \\
\text { más lejos. }\end{array}$ & NISSAN & $20^{\prime \prime}$ & $\begin{array}{l}\text { https://www.facebook.com/ibera } \\
\text { uto/videos/676336379795089 } \\
(*)\end{array}$ \\
\hline
\end{tabular}


revista de recerca i formació en antropologia

\begin{tabular}{|c|c|c|c|}
\hline $\begin{array}{l}\text { iLa ilusión puede } \\
\text { con todo! }\end{array}$ & ONCE & $20^{\prime \prime}$ & https://youtu.be/nNkHTsAQv7o \\
\hline $\begin{array}{l}\text { \# quédateencasa } \\
\text { \#conéctateencas } \\
\text { a }\end{array}$ & ORANGE & $26^{\prime \prime}$ & https://youtu.be/8Wv-tWXgzcE \\
\hline $\begin{array}{l}\text { Cumple tus } \\
\text { propósitos y } \\
\text { quédate en casa. }\end{array}$ & ORANGE & $50^{\prime \prime}$ & https://youtu.be/HkpsdkyR7aM \\
\hline $\begin{array}{l}\text { En Repsol } \\
\text { aplaudimos } \\
\text { vuestra energía. } \\
\text { \# JuntosLoConse } \\
\text { guiremos }\end{array}$ & REPSOL & $45^{\prime \prime}$ & https://youtu.be/gNtZHR9YJoQ \\
\hline \#QuédateEnCasa & RFEF & $76^{\prime \prime}$ & https://youtu.be/yeboMSX_uvk \\
\hline $\begin{array}{l}\text { Protejámoslos, } \\
\text { protegiéndonos } \\
\text { todos. } \\
\text { \#JuntosEnDigital }\end{array}$ & VODAFONE & $30 "$ & https://youtu.be/ANHJzXCY55Y \\
\hline Pronto acabará & VODAFONE & $45^{\prime \prime}$ & https://youtu.be/RwfHsC3oJpw \\
\hline Second round o & rertising & igns & \\
\hline
\end{tabular}




\begin{tabular}{|c|c|c|c|}
\hline $\begin{array}{l}\text { Es momento de } \\
\text { volver a rodar } \\
\text { juntos }\end{array}$ & AUDI & $35^{\prime \prime}$ & https://youtu.be/XBmDrOkI_MU \\
\hline $\begin{array}{l}\text { Fondo Soldiario } \\
\text { Juntos }\end{array}$ & $\begin{array}{l}\text { Bank of } \\
\text { Santander }\end{array}$ & $36^{\prime \prime}$ & https://youtu.be/TWkfHhQJFsw \\
\hline $\begin{array}{l}\text { En Carrefour } \\
\text { garantizamos tu } \\
\text { compra segura } \\
\text { \# JuntosParaAyu } \\
\text { darte }\end{array}$ & Carrefour & $53^{\prime \prime}$ & https://youtu.be/N3bJ0wo093o \\
\hline $\begin{array}{l}\text { Dedicado a la } \\
\text { humanidad }\end{array}$ & Coca-Cola & $60^{\prime \prime}$ & https://youtu.be/6ddj4ojQL8Q \\
\hline $\begin{array}{l}\text { \#FUERZABAR - } \\
\text { Cara a cara }\end{array}$ & Cruzcampo & $30 "$ & https://youtu.be/P3KMIpcDswo \\
\hline $\begin{array}{l}\text { \#UnidosParaCom } \\
\text { ernosEIMundo }\end{array}$ & FIAB & $57 "$ & https://youtu.be/bQB3Q1pNo_8 \\
\hline $\begin{array}{l}\text { SALIMOS MÁS } \\
\text { FUERTES } \\
\text { \#SalimosMasFue } \\
\text { rtes }\end{array}$ & $\begin{array}{c}\text { Spanish } \\
\text { Government }\end{array}$ & $60 "$ & https://youtu.be/yjcJ2hX1d20 \\
\hline $\begin{array}{l}\text { El reparto más } \\
\text { importante } \\
\text { Somos Familia. } \\
\text { \#SomosFamilia }\end{array}$ & MAHOU & $60 "$ & https://youtu.be/Vj1h7XbzY58 \\
\hline
\end{tabular}




\begin{tabular}{|l|l|l|l|}
\hline $\begin{array}{l}\text { Somos familia - Y } \\
\text { las familias se } \\
\text { ayudan. }\end{array}$ & MAHOU & 20" & https://youtu.be/UqdORmYxNCk \\
\#SomosFamilia & ONCE juegas & $20^{\prime \prime}$ & https://youtu.be/qMy_JaHGIp8 \\
$\begin{array}{l}\text { Cuando jugamos } \\
\text { tú, Vuelven } \\
\text { todos. } \\
\text { los iguales. }\end{array}$ & & \\
\hline
\end{tabular}

(*) Currently available on the Brand's Facebook corporate channel.

Once the sample had been selected, analysis of the final repertoire of adverts was based on four successive stages, especially following Caro Almela's consideration of advertising as a powerful social language and other theoretical and empirical studies on the relevance of highly emotional narratives as a strategic communicational device (Escalas and Stern, 2003; Vestergard, 2013): 1) transcription of voiceovers and text messages; 2) quantitative coding of some basic categories concerning audiovisual language in all units (length, voiceovers, captions and titling, images and settings, etc.); 3) a qualitative review, based on thematic analysis of each selected unit following Roberts and Pettigrew's proposal (2007), and, finally 4) a comparison of the quantitative and qualitative variables from both rounds of advertising.

\section{Major narratives in audiovisual advertising}

\section{The first round of adverts: the beginning of the lockdown}

On 14th March 2020, the Spanish government formally declared a national state of emergency, as part of which it announced an extensive range of containment measures to mitigate the spread of COVID-19 for an initial period of two weeks (which was ultimately extended to over three months, including several stages of deescalation). What this declaration meant for most of the Spanish population was confinement (only essential personnel were excluded while on duty), thus limiting people's presence outside their homes to when they were carrying out indispensable activities. The Spanish premier stated that: "Heroism also consists of washing your 
hands and staying at home. We are going to stop the virus with responsibility, and with unity" (Cué, Pérez and García, 2020). The hashtag \#Quédateencasa [\#Stayathome] soon became omnipresent across a broad swathe of conventional and digital media before being virally replicated by various companies and institutions, even private brands adding it to their commercial activity.

In this first round of advertising campaigns, only $52.2 \%$ of the sample units had voice-overs ( $50 \%$ used a male voice, $25 \%$ a female one and the other $25 \%$ a combination of male and female voices), while $91.3 \%$ had some form of textual message. Excluding articles, prepositions, pronouns and other words with no substantive meaning in and of themselves, the most frequently used words were, in this order: "Home", "Stay", "Can" and "Together". Beyond the statistical bias that may have been introduced by the prevalence of the hashtags \#Quédateencasa and \#Yomequedoencasa [\#I'mstayingathome], which became ever-present phrases in most commercials and institutional advertising, agencies elaborated on these formulae to obtain specifically adapted references that combined the general concern with the specific quality of the brand:

"Together we can adapt to a new environment. We are here to help you [...] We'll overcome this together [...] To achieve this as soon as possible: use digital channels. Pay by card or mobile. Practise good hygiene and wash your hands frequently. Maintain a safe distance of 1 to 2 metres. And, if you can, please stay at home" (Bank of Santander).

"To the right and to the left. Sharp and smooth. On mud, snow and water. We have mastered even those that seemed impossible. But we can only master this curve together" (Audi).

Hence, major narrative themes during this period were:

1) A strong sense of communitas, based on common exposure to an unexpected threat and the collective effort required to overcome it. Despite the fact that no explicit representation of the virus nor overt allusion to the disease were evident on screen, the identification of a tacit, shared hindrance and the mutual concern the context demands to keep the menace under control led to a distinct narrative of togetherness and mutual belonging. As Turner proposed (1969), new social liturgies appeared as a part of the advent of a collective ritual: washing hands, 
wearing masks and avoiding close physical contact were individual actions that created a new social closeness. Collective habits changed and took on ritualised patterns that may create tight symbolic bonds between practitioners (not least the increased exchange of good wishes in formal and informal interpersonal communications). Regarding this theme, $52.2 \%$ of the sample units explicitly used the word "together", but another $43.5 \%$ used related expressions: "all of us", "all united", "for all", "all people", "all families", etc.

2) Tightly bound to this sense of unity came the objective of getting over the crisis. Fifty per cent of the sample literally or metaphorically called on viewers to stay strong and to overcome the crisis, while another $25 \%$ talked about returning to normal and resuming former routines:

"The race has begun. And to win you have to step on the brake. So ... stop! Stay at home and take good care of yourself. Because you know: together we'll go further". (Nissan)

"We will get back to your bar, to your daylight. To your tables, to your beers. We will hug, touch, feel again. Listen carefully: we will return. I don't know if tomorrow, the day after, or when it will be. But we will be back". (Mahou beer)

3) Similarly, appeals to collective responsibility and mutual protection are common in these narratives: $56.5 \%$ of the sample units explicitly refer to this concern. The former appeared more explicitly in institutionally funded ads ("Be responsible and for the good of us all, stay at home", RFEF; "Containing the coronavirus is everyone's responsibility", the Catalan government), while the latter is clearly mentioned in both commercial and institutional ads: "Now more than ever, we are with our elders. Let's protect them by protecting all of us" (Vodafone); "If you protect yourself, you're protecting others" (the Spanish government).

4) Interestingly, despite the strong sense of gratitude towards those collectives identified as providing essential services and, in some cases (the health services) often labelled as "heroes" in the general media, only $22 \%$ of the sample explicitly thank them. Nearly all of the ads that do are private sponsored commercials.

5) There were also some representations of major social changes. One significant social impact within the internal Spanish labour market was the increase in remote working practices. According to Eurofound (2020), 30.2\% of Spanish 
workers started to work from home as a result of the COVID-19 pandemic, and this seems to be a situation that will be with us for the long-run (RodríguezFerrand, 2020), but only $13 \%$ of the ads refer explicitly to that issue. Other topics such as hoaxes and intentional misinformation, which attracted media attention due to their rapid spread during the initial weeks of the pandemic (del Riego, 2020) only merit one tangential allusion within a simulated dialogue in an institutional ad.

Similarly, despite being one of the European countries with the highest proportion of people living under the poverty threshold (Alston, 2020; Fernández, 2019), very few explicit mentions of vulnerable people were to be found in this first round of coronavirus-related advertising. Leaving aside one commercial sponsored by ONCE addressing people with disabilities, only an institutional ad produced by the Catalan government overtly called on viewers to "protect the most vulnerable people". However, allusions to vulnerability are traceable in some other institutional ads: "Mum, listen, I'm going to stay in Madrid, I've already thought about it and I'm going to stay here, okay?" [no image of elderly people is shown, though] (Spanish government). And in another example: "Mariana, I'm going shopping. If you need something, just tell me and I'll bring it to you, right? But you are not going to leave home" [there is no image of who Mariana may be, though the speaker's use of the formal Spanish pronoun suggests that she may be an elderly neighbour] (Spanish government). The only commercial advert clearly showing vulnerable groups was a Vodafone campaign, which included the statement: "Now more than ever, we're with our elders. Let's protect them by protecting all of us" (the advertised item was a smartphone with videocall functionality).

\section{The second round of advertising: the start of the de-escalation process}

Some weeks after the lockdown had begun, the Spanish government created a "deescalation" plan comprising four successive stages designed to gradually lead to the so-called "new normality" (Moncloa Palace, 2020). The entrance into the first of these stages ended the population-wide lockdown and brought with it a new kind of information, based on the advances and setbacks of different autonomous communities (the government considered this an "asymmetrical" process, though nearly all of the country entered into that "new normality" by the end of June). Would 
any kind of societal change be reflected in advertising productions after two months of strict confinement?

To begin with, a change in magnitude was evident: the number of campaigns specifically referring to this new situation dropped by $56.5 \%$, as audiovisual units from only nine brands/institutions were found at that time, although this does not necessarily entail a lack of interest on their behalf.

During this round of advertising campaigns, $60 \%$ of the sample included voiceovers: $50 \%$ used male voices, $33.3 \%$ female ones and $16.7 \%$ combined male and female voices, while $90 \%$ displayed some form of textual message. The most frequently repeated substantive words in these units were: 'Family/families', 'Be back/come back/go back' and 'Together'. However, beyond specific keywords, scripts reflected a clear change in relation to the previous round of advertising. While messages of encouragement once prevailed, notions of reconstruction and support were now widespread. One of the spots presented a song made expressly for the commercial (the male singer even wore a digitalised mask that was added at the post-production stage), which summed up this idea very well: "The clouds go away and the sun starts shining once more. With your effort you can beat all this and smile again. Be happy again!" (Carrefour). Optimism and the value of sacrifice appear in the background of many different scripts: "Holding on isn't easy. But we have done it. Actually, we always have. Because here, surrendering isn't really our thing. We are fighters [...] We come out stronger" (Spanish government); "The moment you've been waiting for has arrived" (Orange); "We had to stop so that we could enjoy [life] again" (Audi).

The main narratives identified during this phase are as follows:

1) The idea of coming back is verbalised in some way in $60 \%$ of the units. Similarly to Van Gennep's (1909) integration phase in a rite of passage, after a collective period of enforced reclusion, in the gradual reincorporation into social life and the reintroduction of daily activities into public places, there is an interesting duality between the domestic and public domains. Home is now being visually opposed to spaces of socialisation, which take on the more positive characteristics often associated with the former: familiarity, joy and mutual support: "This world [a man sings in the supermarket] is our home and we must take care of it" (Carrefour); "Until recently we celebrated everything around a table, on a terrace 
next to a bar, or in a kitchen. Anything was worth organising a meal to celebrate it or to have a drink [...] We have to get together again" (FIAB); and: "Each one of you [the workers] who goes the extra mile in every bar, in every restaurant: you are our family [...] We have come together as families do" (Mahou beer).

2) Closely related to this reconnection narrative, $50 \%$ of the ads make explicit messages about resilience and overcoming challenges: "We find a way to stay united [...] To all the heroes of humankind. Thank you all for seeing the glass as half-full" (Coca-Cola); "Enduring this situation has not been easy. But we have done it [...] We're coming out stronger" (Spanish government). The idea of having come back is also present in other commercials that refer to the brands' products (lottery, drinks and smartphones) but metaphorically refer to the beginning of the end of domestic confinement. Ads using videos show smiling people in (half) empty settings such as sports stadiums, supermarkets, bars, streets and bus stations, which may remind us of Augé's non-places (1995) and provide a powerful audiovisual counterpoint to spaces filling up again as musical crescendos establish the dramatic tempo.

Smiling faces also appear with slightly greater frequency in this round of adverts (56.5\% versus $60 \%$ ), although the difference does not seem significant enough to comment on the depiction of emotional differences between the two phases.

3) Social spaces and atmospheres: while, at the beginning of the lockdown, $21 \%$ of the sample showed hospital settings as part of the background, at the beginning of the de-escalation phase, this percentage rose to $30 \%$. The first round of adverts employed either close-up shots of health personnel getting ready to work or clapping their hands and cheering the patients leaving $A \& E$. The second round of adverts included some more explicit shots showing patient examinations, PCR testing and patients on ventilators, with face masks and Personal Protective Equipment (PPE) being much more visible: $30 \%$ versus $60 \%$.

4) Concurrently, as mentioned above, togetherness was an explicit ingredient in $60 \%$ of the sample: slightly higher than in the first round of advertising. The sense of communitas seems to have been strengthened after the period of confinement and scripts and audiovisual situations clearly show this, both literally and metaphorically: "We stand together to help you" (Carrefour); "We do it all 
together" (Mahou beer); "For every metre that separates us, empathy brings us closer" (Coca-Cola); "We have to come together again, to join forces, because that is the only way to overcome this crisis" (FIAB); "When you play, we all play" (ONCE).

A subtle qualitative turn may be noted, as the cohesion of this community now comes not only from the adversity it faces, but from the shared effort and sacrifice made over the past two months. In this light, the strong appeal to become a symbolic family (Mahou beer) and the use of a popular movie basketball team (ONCE) as a cultural symbol for unity, support and companionship stand together with recurrent references to people's strength and will to overcome adversity. Hence, during the reintegration into social life, we are represented as being the same as always, but with an added dose of determination and success: both continuity and transformation. Given that complying with lockdown was an individual responsibility, it could only be made effective through the collective aggregation of individual accomplishments. And, as in rites of passage, this time of reclusion was a liminal period that imprinted a certain character on the collective. Members of this new communitas acquire this character by means of resilience and a firm will for continuity. By returning to those activities and scenarios that were an essential part of social (and economic) life before the lockdown, this newly acquired status is proved. As the Cruzcampo beer commercial showed, going back to your favourite bar symbolically ties continuity and transformation together: "Go back to the bar where you drank your penultimate one to have The First One".

5) As already seen in the first round of coronavirus-related adverts, there are very few explicit mentions of "heroes" in the second round (only one advert), but scripts do stress the strengthened character needed to face the pandemic and finally succeed in bending the curve. In a sense, the epic resonance of heroic narratives is extended to the whole community, rather than focused on certain groups, although these are visually present on screen. The notion of a group, then, is not only based on a mutuality of being, as Sahlins (2013) characterised kinship, but on a mutuality of sharing and experiencing together, with certain elements of Carsten's (2000) notion of relatedness and the unity engendered by sharing common duties and activities. 
6) As in the first round of advertisements, remote working was not a predominant theme at this stage. Actually, there was no explicit reference to such activity, although some visual frames in certain spots may have alluded to it (e.g. a man wearing headphones, seemingly talking to a camera). It may be hypothesised that the commercial brands represented do not regard remote workers to be specific targets and prefer to call for physical trips to material locations (bars, roads, restaurants, etc.), but institutional ads do not refer to them either. An alternative hypothesis is that the main goal of all these advertising productions is to highlight the collective endeavour in response to the pandemic and to congratulate viewers for their success in overcoming the difficulties of confinement, which may have more narrative impact when represented in the material dimension than through a digital community. In fact, and to the extent that this sample allows us to draw conclusions on this matter, the digital turn that this unexpected pandemic has obliged many to take seems not to be a central narrative within audiovisual advertising.

The same may be said regarding societal concern for hoaxes and fake news, which is completely absent from the selected sample. None of the advertised campaigns address media reliability or trust in information sources, and no awareness-raising campaign meeting the sampling criteria has been located within this second round of advertising.

\section{Conclusion}

Despite being in the middle of the pandemic, running a considerable risk that much of what could be said about this moment will later be proven wrong (Appadurai, 2020, p. 1), certain cultural narratives about the impact of COVID-19 and the reactive governmental proposals that led to a rather strict lockdown in order to first flatten and later bend the curve of infections have already become quite evident. As previous studies have suggested, audiovisual advertising, either sponsored by institutions or by private brands, offers us a neat combination of tactical branding and intentional narratives that deliberately emphasise certain social values as part of strategic processes of empathy and identification aimed at securing target audiences' engagement, beyond mere contemplation (Escalas and Stern, 2003; Vestergaard, 2013). 
The social values selected primarily revolve around social cohesion, by emphasising the sense of communitas that arises from shared exposure to a collective danger which can only be overcome by the aggregation of individual efforts. Hence, togetherness and overcoming have become crucial symbolic assets, both during the first round of coronavirus-related advertising (at the beginning of the lockdown) and the second one (at the beginning of the de-escalation period).

However, very few specific mentions of vulnerable people are found in both rounds of adverts, which may certainly be surprising, given the significant impact of the pandemic upon such collectives. Maybe this omission could be explained by the commercial condition of the advertising sample, as those social groups may not be specific targets for the brands in question. However, such a hypothesis cannot be confirmed at this stage and further research should explore this issue in greater depth by including advertisers within a multi-modal approach. It may be also surprinsing the the lack of references to remote working, precisely in a context where the digital turn and online activities have experienced considerable growth that seems to be of an enduring nature (Rodríguez-Ferrand 2020). Seemingly, the brands and institutions sponsoring the ads in this sample were more interested in the physical dimension of recovery than in the digital benefits of new technologies (online banking, online shopping, etc.).

On a visual level, adverts from both periods included both indoor and outdoor settings. The duality between home (private) and spaces of socialisation (public) is pervasive, and the recurrent appearance of sports stadiums, supermarkets, bars, streets and bus stations call to mind Auge's (1995) non-places, as well as the relevance of casual interactions in creating a sense of community.

Narratively, the units analysed play with the underlying notion of suspended time (a time for resilience), as events take place during an indefinite stretch of time that reconfigures collective action by encouraging individual responsibility for an indefinite period. In the scripts, verb tenses repeatedly place us in timeless periods that strengthen the core messages even further: a necessary pause enabling us to set out again afterwards, with the shared experienced that becomes a symbolic glue joining social beings together by obliterating the diverse sociocultural differences under the skin of this intended community. Indeed, there are appreciable differences between institutional and commercial spots, being the latter more focused on the product 
itself, which is narratively invested in most units with solid social values that pervade official messages at the time. The former, in turn, are focused on ample general sanitary warnings during the first wave, turning to a certain sense of self-satisfaction during the second round. The invisibility of certain social groups (i.e. the most vulnerable ones) and the lack of explicit precarious situations confer the overall sample (be it institutional or commercial ads) a specific tone of good-natured propaganda.

However, this emphasis may be an exercise of corporate social responsibility (CSR). Actually, some studies stress the great opportunities this pandemic is offering to the advertising industry since our attitudes and opinions, as consumers, are changing during significant breakdowns, and marketers could take good advantage of adapting their policies and strategies accordingly (He and Harris, 2020:181). However, this hypothesis should be tested in further studies by adopting multi-modal research approaches to both producers and consumers altogether.

In conclusion, cultural narratives during the lockdown period in Spain emphasise the unified character of the community -although this unity embeds significant omissions-, with a conceptual basis in the mutuality of sharing - a concept that draws upon Sahlins' notion of the "mutuality of being" (2013) - as the participation in one another's experience leads to an interdependent existence (idem) that solidifies the sense of togetherness. Thus, beyond nationality, citizenship or other supra-individual markers, having shared a common traumatic experience reinforces the collective self in a way probably no other symbolic cement may achieve.

As ethnographers, we know that it is not uncommon for the unexpected to occur (Canals, 2020), forcing us to pay attention to new social issues that not only shape powerful imageries, but also generate cultural narratives which account for new forms of awareness and sensibilities. Certainly, the colossal scale of the current COVID-19 crisis has set in motion an interconnected chain of social, economic and political events whose effects have only begun to be revealed, but that deserve all our attention. And not only scrutiny of the events themselves is needed, but also of the ways in which they are narratively reported.

However, this research has several limitations. To begin with, the repertoire of audiovisual productions was limited to those aired in certain weeks at two very 
specific moments in the reaction to the pandemic. A wider survey might produce different outcomes. Secondly, I selected public TV stations as broadcasting platforms, due to their extensive coverage within each territory (both at a regional and a national level), but expanding the repertoire to other media types and advertising formats in the future could provide a different picture of the situation. Thirdly, I focused exclusively on the audiovisual field. Future research may extend these insights by using a multi-modal methodology which involves other relevant links in the advertising chain (creative teams, advertisers, casting agencies, etc.). Finally, a more specific compositional analysis could be undertaken by future studies, ranging from colour-palettes to formal elements of the audiovisual language (in-depth sound analysis, storyboards, and so on) so the kind of thematic analysis undertaken here could be merged with a more visually-driven formal examination.

\section{References}

Advertiser Perceptions. (2020). Coronavirus Effect on Advertising Report. New York. Retrieved from https://www.advertiserperceptions.com/wpcontent/uploads/2020/03/03.25.2020-Coronavirus-Effect-on-AdvertisingWEBINAR-PDF-1.pdf

Alston, P. (2020). Statement by Professor Philip Alston, United Nations Special Rapporteur on extreme poverty and human rights, on his visit to Spain, 27 January - 7 February 2020.

Anta, J.-L. (2020). Acontecimiento y control social. El Régimen de confinamiento durante el Covid-19. Periferia, 25(2), 216-226. https://doi.org/https://doi.org/10.5565/rev/periferia.745

Appadurai, A. (2020). The COVID exception. Social Anthropology, 0(0), 1-2. https://doi.org/https://doi.org/10.1111/1469-8676.12898

Augé, M. (1995). Non-places: Introduction to an Anthropology of Supermodernity. London, New York: Verso.

Bauchner, H., \& Easley, T. J. (2020). Health Care Heroes of the COVID-19 Pandemic. JAMA - Journal of the American Medical Association, 323(20), 2021. https://doi.org/10.1001/jama.2020.6197

Bennett, R., \& Daniel, M. (2002). Media reporting of Third World disasters: the 
journalist's perspective. Disaster Prevention and Management: An International Journal, 11(1), 33-42. https://doi.org/10.1108/09653560210421682

Biscop, S. (2020). Coronavirus and Power: The Impact on International Politics. Security Policy Brief, 126, 1-4.

Brader, T. (2005). Striking a Responsive Chord: How Political Ads Motivate and Persuade Voters by Appealing to Emotions. American Journal of Political Science, 49(2), 388-405. $\quad$ https://doi.org/https://doi.org/10.1111/j.0092$5853.2005 .00130 . x$

Browne, B. A. (1998). Gender Stereotypes in Advertising on Children's Television in the 1990s: A Cross-National Analysis. Journal of Advertising, 27(1), 83-96. Retrieved from http://www.scopus.com/inward/record.url?eid=2-s2.0$\underline{0002580804 \& \text { partnerID }=40 \& m d 5=a b 9598295 a f a 196 c 6 f 76 b e 895 f c 76 c 8 f}$

Canals, Roger. 2020. "Dealing with the Unexpected: New Forms of Mytho-praxis in the Age of COVID-19." Social Anthropology 0 (0): 1-2. https://doi.org/https://doi.org/10.1111/1469-8676.12808.

Caro Almela, A. (2007). Fundamentos epistemológicos y metodológicos para un estudio científico de la publicidad. Pensar La Publicidad., 1(1), 55-82. https://doi.org/-

Carsten, J. (2000). Introduction: Cultures of Relatedness. En J. Carsten (Ed.), Cultures of Relatedness. (pp. 1-36). Cambridge: Cambridge University Press.

Casero-Ripollés, A. (2020). Impact of covid-19 on the media system. Communicative and democratic consequences of news consumption during the outbreak. Profesional de La Informacion, 29(2), 1-11. https://doi.org/10.3145/epi.2020.mar.23

Chang, C., \& Lee, Y.-K. (2009). Framing Charity Advertising: Influences of Message Framing, Image Valence, and Temporal Framing on a Charitable Appeal. Journal of Applied Social Psychology, 39(12), 2910-2935. https://doi.org/10.1111/j.1559-1816.2009.00555.x

Cué, C., Pérez, C., \& García, E. (2020, March 13). Spanish government declares state of alarm. El País (Online edition). Retrieved from https://english.elpais.com/politics/2020-03-13/spanish-government-declares- 
state-of-alarm-in-bid-to-combat-coronavirus-spread.html

del Riego, C. (2020, April 27). España detecta 200 acciones de desinformación bajo la alarma. La Vanguardia (Edición Digital).

Donthu, N., \& Gustafsson, A. (2020). Effects of COVID-19 on business and research. Journal of Business Research, 117, 284-289. https://doi.org/10.1016/j.jbusres.2020.06.008

Escalas, J. E., \& Stern, B. B. (2003). Sympathy and Empathy: Emotional Responses to Advertising Dramas. Journal of Consumer Research, 29(4), 566-578. https://doi.org/10.1086/346251

Eurofound. (2020). Work, teleworking and COVID-19.

Farris, N. (2014). The proof is in the pudding: Gender specific stereotypes in television advertisements. In N. Farris, M. A. Davis, \& R. Compton (Eds.), Illuminating How Identities, Stereotypes and Inequalities Matter through Gender Studies (pp. 71-81). University of West Alabama, Livingston, AL, United States: Springer. https://doi.org/10.1007/978-94-017-8718-5_6

Fernández, G. (2019). VIII Informe sobre exclusión y desarrollo social en España. Madrid. Retrieved from https://caritas-web.s3.amazonaws.com/mainfiles/uploads/sites/16/2019/05/Informe-FOESSA-2019-completo.pdf

Grau Rebollo, J. (2020). "El papel de la publicidad en el abordaje de la vulnerabilidad social. Panorama y reflexiones a propósito del caso español". Intexto, 49, 1840. https://doi.org/10.19132/1807-8583202049.18-40.

He, Q., Liu, J., Wang, S., \& Yu, J. (2020). The impact of COVID-19 on stock markets. Economic and Political Studies, 1-14. https://doi.org/10.1080/20954816.2020.1757570.

He, H., \& Harris, L. (2020). The impact of Covid-19 pandemic on corporate social responsibility and marketing philosophy. Journal of Business Research, 116, 176-182. https://doi.org/10.1016/j.jbusres.2020.05.030.

Hennekens, C. H., George, S., Adirim, T. A., Johnson, H., \& Maki, D. G. (2020). The Emerging Pandemic of Coronavirus and the Urgent Need for Public Health Leadership. The American Journal of Medicine, 133(6), 648-650. 
https://doi.org/10.1016/j.amjmed.2020.03.001

Kantar Media. (2020). Anuario Social de TV 2019. Madrid, Sant Cugat. Retrieved from https://www.kantarmedia.com/es/blog-y-recursos/data-lab/anuario-social-tv2019.

Lee, T. D., Chung, W., \& Taylor, R. (2011). A strategic response to the financial crisis: an empirical analysis of financial services advertising before and during the financial crisis. Journal of Services Marketing, 25(3), 150-164. https://doi.org/https://doi.org/10.1108/08876041111129146

Martin, A. (2019). What are the Differences Between Advertisements and Commercials?, Chron, website: https://smallbusiness.chron.com/differencesbetween-advertisements-commercials-10353.html.

Moncloa Palace. (2020). Government approves de-escalation plan which will gradually be implemented until end of June. Retrieved July 6, 2020, from La Moncloa website: https://www.lamoncloa.gob.es/lang/en/gobierno/councilministers/Paginas/202 0/20200428council.aspx

Nielsen. (2020a). Staying put: consumers forced indoors during crisis spend more time on media. Retrieved July 2, 2020, from Nielsen.com website: https://www.nielsen.com/us/en/insights/article/2020/staying-put-consumersforced-indoors-during-crisis-spend-more-time-on-media/

Nielsen. (2020b). The impact of covid-19 on media consumption across North Asia. Retrieved July 2, 2020, from Nielsen.com website: https://www.nielsen.com/apac/en/insights/report/2020/the-impact-of-covid19-on-media-consumption-across-north-asia/

Potter, C. W. (2001). A history of influenza. Journal of Applied Microbiology, 91(4), 572-579. https://doi.org/10.1046/j.1365-2672.2001.01492.x

Roberts, M., \& Pettigrew, S. (2007). A thematic content analysis of children's food advertising. International Journal of Advertising, 26(3), 357-367. https://doi.org/10.1080/02650487.2007.11073018

Rodríguez-Ferrand, G. (2020, June 25). Spain: Government Employees Authorized to Telework up to Four Days a Week. 
Sahlins, M. (2013). What Kinship is - And is Not. The University of Chicago Press: Chicago and London.

Sánchez, M. Á. (2020). Estudio Infoadex de la inversión publicitaria en España. Madrid.

Šerić, N., \& Ljubica, J. (2018). Market research methods in the sports industry. Wagon Lane, Bingley: Emerald Publishing. Retrieved from http://obrasociallacaixa.org/en

Sanfilippo, F., Bignami, E., Lorini, F. L., \& Astuto, M. (2020). The importance of a "socially responsible" approach during COVID-19: The invisible heroes of science in Italy. Critical Care, 24(1). https://doi.org/10.1186/s13054-020-02998-0

Scopen. (2020). Trend Score España. Especial Covid-19. Madrid.

Taylor, C. R. (2020). Advertising and COVID-19. International Journal of Advertising, 39(5), 587-589. https://doi.org/10.1080/02650487.2020.1774131

Torres, I., \& Briggs, E. (2007). Identification Effects on Advertising Response: The Moderating Role of Involvement. Journal of Advertising, 36, 97-108. https://doi.org/10.2753/JOA0091-3367360307

Turner, V. (1969). Liminality and Communitas. En The Ritual Process: Structure and Anti-Structure (pp. 94-113). Chicago: Aldine Publishing Company.

Van Gennep, A. (1909). Les rites de passage. Paris: Emile Nourry.

Vestergaard, A. (2013). Humanitarian appeal and the paradox of power. Critical Discourse Studies, 10(4), 444-467. https://doi.org/10.1080/17405904.2012.744322

Vorhaus, M. (2020, April 27). COVID-19 represents the biggest challenge to media advertising expenditures ever. Forbes. Retrieved from https://www.forbes.com/sites/mikevorhaus/2020/04/27/covid-19-representsthe-biggest-challenge-to-media-advertising-expendituresever/\#5b207e357398

Žižek, S. (2020). Pandemic!: COVID-19 Shakes the World. Cambridge: Polity. 